LA-6890-MS

Informal Report

\section{Downhole Electrical Detection of Hydraulic Fractures in GT-2 and EE-1}

UC-66b

Issued: July 1977

P. R. Kintzinger

F. G. West

R. L. Aamodt

An Aftirmative Action/Equal Opportunity Employer 


\section{DISCLAIMER}

This report was prepared as an account of work sponsored by an agency of the United States Government. Neither the United States Government nor any agency Thereof, nor any of their employees, makes any warranty, express or implied, or assumes any legal liability or responsibility for the accuracy, completeness, or usefulness of any information, apparatus, product, or process disclosed, or represents that its use would not infringe privately owned rights. Reference herein to any specific commercial product, process, or service by trade name, trademark, manufacturer, or otherwise does not necessarily constitute or imply its endorsement, recommendation, or favoring by the United States Government or any agency thereof. The views and opinions of authors expressed herein do not necessarily state or reflect those of the United States Government or any agency thereof. 


\section{DISCLAIMER}

Portions of this document may be illegible in electronic image products. Images are produced from the best available original document. 
Printed in the United States of Amcrica. Available from National Technical Information Service

U.S. Department of Commerce

5285 Port Royal Road

Springfield, VA 22161

Price: Printed Copy $\$ 3.50$ Microfiche $\$ 3.00$

4.2

This report was prepared aw an account of work sponsored by the lented slates fiovernment. Nelither the United states nor the lnited Slat's Bncreg Rescarch and Bevelopment Ad

ministration, nor anc or heir employess, nor any of their con-

warrants express or imolied or a ssumes any leg hl liability or

responsibility for the accuracy. completenesw, or usefulness of

any information. apparalus, product. or process disclosed, or

represeqts that is use would not infringe privately owne
righls. 
DOWNHOLE ELECTRICAL DETECTION OF HYDRAULIC FRACTURES IN GT-2 AND EE-1

by

P. R. Kintzinger

F. G. West

R. L. Aamodt

\section{ABSTRACT}

Electrical geophysical methods including mise à la masse and self-potential (SP) for determination of hydraulic fracture characteristics have been used at Los Alamos Scientific Laboratory's hot dry rock geothermal project.

Electrical and induction logs have indicated that the resistivity contrast between the granite and $200^{\circ} \mathrm{C}$ water at the $2926-\mathrm{m}$ (9600-ft) depth is a factor of 1000 or more, Thus the water in a hydraulic fracture, formed to connect two adjacent deep holes, is a good conductor compared to the confining granite. Mise à la masse-type measurements have been made to help determine the characteristics for hydraulic fractures formed in each of the two geothermal holes GT-2 and EE-1. Once a hydraulic fracture has been formed, mise à la masse effects are obtained both with the fracture pressurized above hydrostatic and when depressurized to hydrostatic. This indicates that once the fracture has been created, enough natural propping exists that a conductive zone persists even when the fracture is deflated.

A fracture was formed in a $18-\mathrm{m}$ (60-ft) zone immediately below $1957 \mathrm{~m}(6420 \mathrm{ft})$ in EE-1. Later a set of SP logs was run in this zone with no pressure, with pressure building, with pressure decreasing, and again with the fracture depressurized. Results show that during times of change of parameters in hydraulically fractured regions in the hole, natural SP logging helps to determine the position of the fracture. However, after a fracture has come to equilibrium with fluid parameters such as temperature, pressure, salinity, and $\mathrm{pH}$, an effect of the fracture may not be evident. 
Self-potential logs provide an excellent method for locating the bottom of steel casing that has been set in the hole.

\section{INTRODUCTION}

The Los Alamos Scientific Laboratory is investigating methods of extracting geothermal energy from hot, low-permeability, dry rock in the crust of the earth. The system is based on the creation of a pressurized water circulation loop formed by drilling two holes from the surface of the earth and connecting them by means of a large crack system produced by hydraulic fracturing. ${ }^{1,2}$

One procedure may be to drill one hole, hydraulically fracture at the desired depth, determine the vertical extent and orientation of the hydraulic fracture, and then drill the second hole to intersect the fracture. Therefore, it is important to develop techniques for determination of the orientation, size, and shape of the fractures that have been produced.

The electrical methods described herein utilize the mise $\underline{\text { à }}$ la masse and self-potential techniques. In the mise à 1 a masse method, which was suggested by Schlumberger in $1920,{ }^{3}$ a subsurface conductive mass is used as one current electrode of a pair and the second current electrode is placed in a well-watered shallow pit at some distance away. ${ }^{4,5}$ While an electrical current is flowing, potentials on the surface or in an adjacent borehole (Fig. 1) are then recorded to try to outline the extent, shape, and azimuth of the conductive mass.

From an analysis of electrical and induction logs ${ }^{6}$ in GT-2 and EE-1 and deep resistivity results from the area, ${ }^{7}$ it can be seen that the resistivity contrast between the crystalline rock and the $200^{\circ} \mathrm{C}$ water is a factor of 1000 or more. Thus the water-filled fracture is a very good electrical conductor compared to the confining low-permeability granitic rock.

At a later date it is planned to make surface potential field measurements while energizing the downhole hydraulic fracture; however, so far preliminary two-hole mise à la masse experiments have been done along with natural background self-potential logging runs. No surface potential field mapping of mise à $\underline{\text { a }}$ masse experiments has been done.

The help and advice of Dr. George Jiracek and several of his students from the University of New Mexičo have been greatly appreciated. 
INDUCED POTENTIAL TWO-HOLE LOGGING

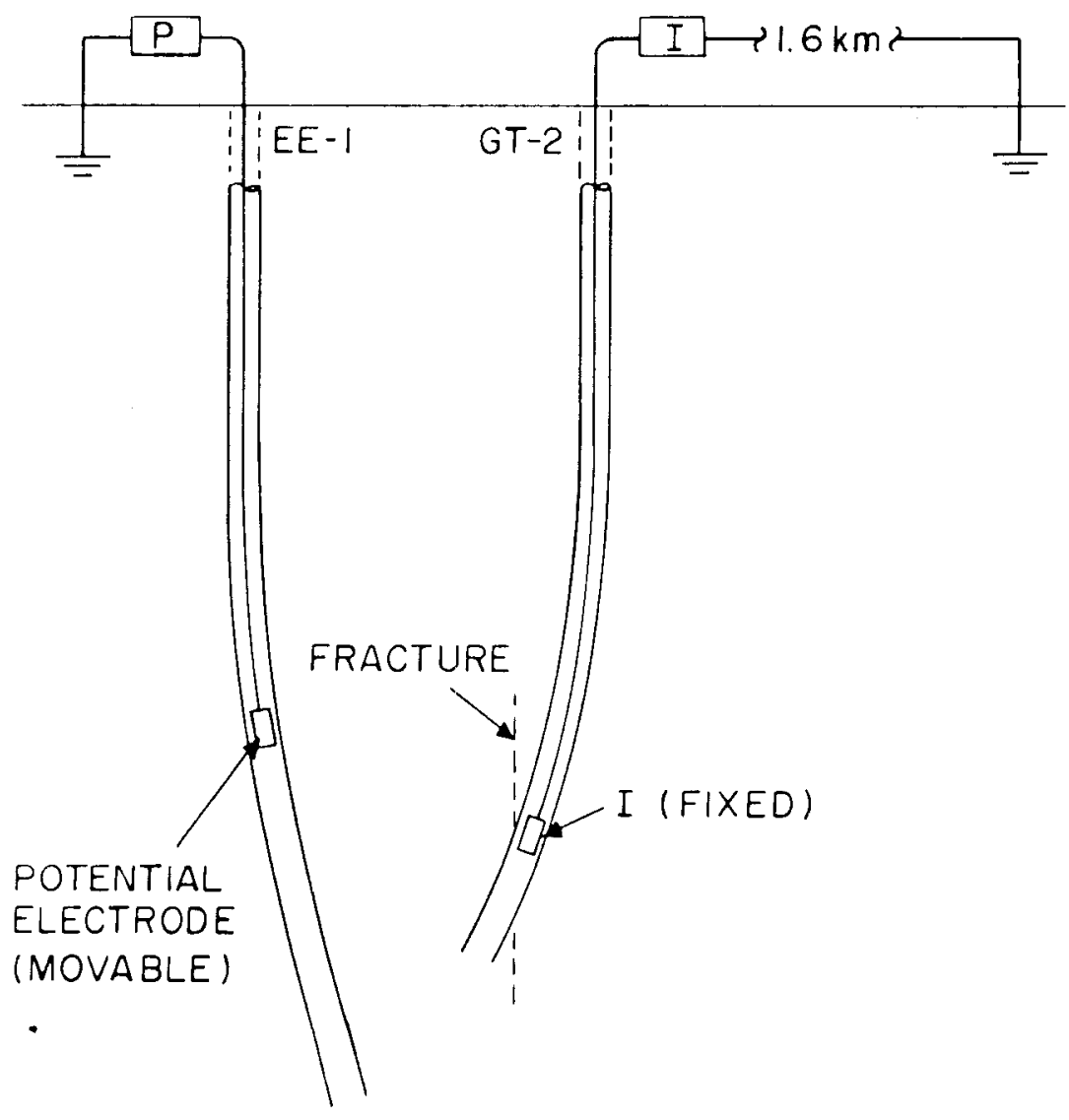

Fig. 1 .

Induced potential two-hole logging.

II. MISE $\underline{\mathrm{A}}$ LA MASSE TWO HOLE MEASUREMENTS

GT-2 was drilled to a depth of $2928.2 \mathrm{~m}$ (9607 ft) and a steel liner about $183 \mathrm{~m}$ (600 ft) long was cemented in the bottom of the hole. An unlined rat hole was then drilled extending about $12 \mathrm{~m}$ ( $38 \mathrm{ft}$ ) below the bottom of the steel liner. The bottom of the hole was then pressurized several times and a 151416 liter (40 000-gal) hydraulic fracture was formed.

In order to determine the vertical extent of this fracture the first mise à 1 a masse experiment was done as shown in Fig. 1 . The current electrode was stationary in the fracture zone at the bottom of GT-2 and a moveable potential logging electrode was used in EE-1.

Figure 2 shows the type of signal recorded during a logging run in EE-1 during excitation of the GT-2 fracture with a 7-sec-period square wave current of about 1.8 amperes peak to peak. A marked increase in signal size can be seen between the 2786-m $(9140-f t)$ and 2820-m (9250-ft) depth. 


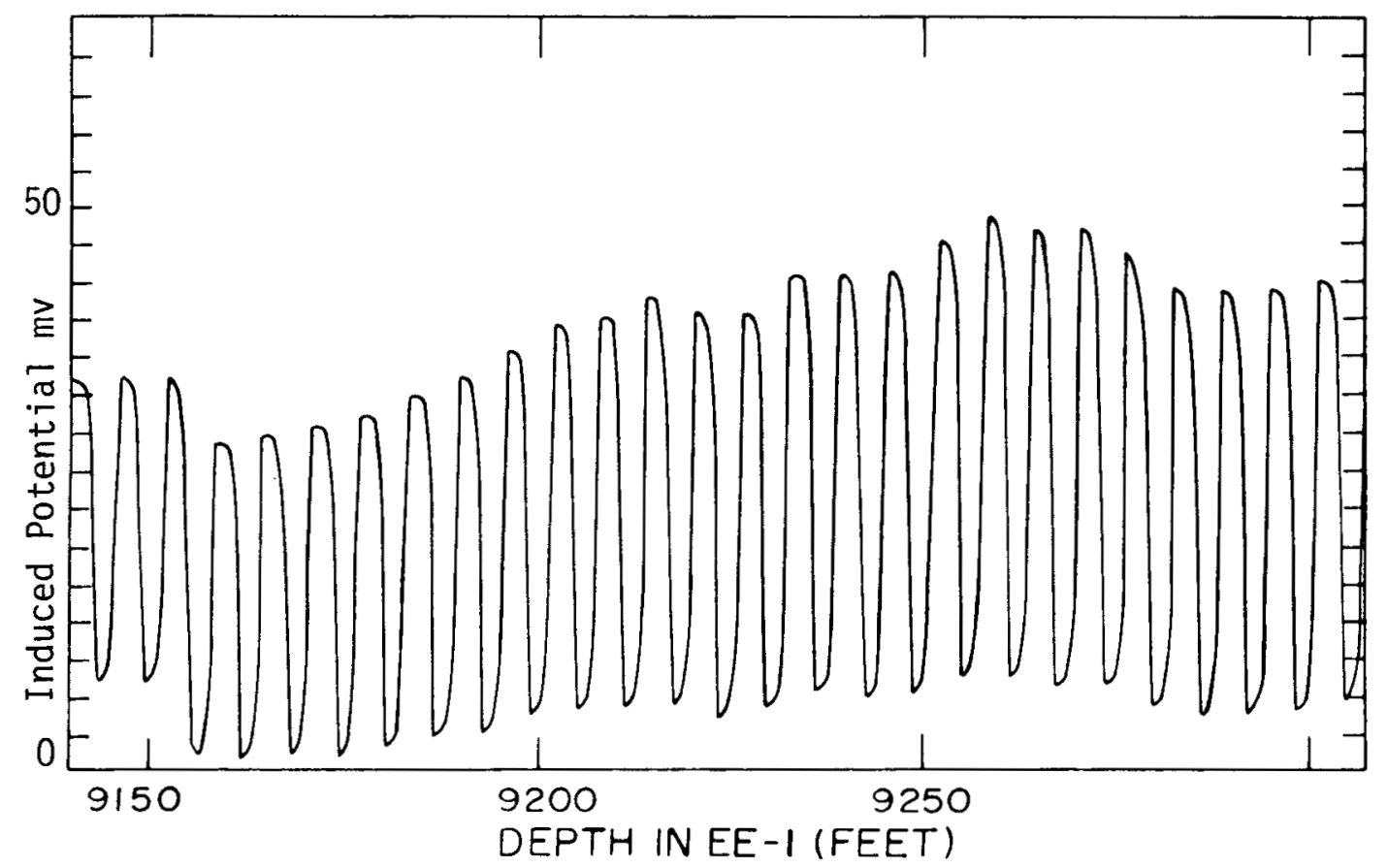

Fig. 2.

Logging record. Fracture in GT-2 excited, induced potential logging in EE-1.

Figure 3 is a graph of two different logging runs, one with the fracture inflated with 13250 liters (3500 gal) of water and one with the fracture deflated. Induced potentials plotted in Figs. 3 and 4 are in millivolts (mV) peak to peak. The graph for the open fracture indicates a conductive zone extending upward to approximately the 2804-m (9200-ft) level in GT-2. A conductive zone formed by the cemented-in liner near the bottom of the hole can be seen on the graph.

The trace in Fig. 3 for the fracture closed also defines a conductive zone for the fracture. The signal, however, is smaller due to decreased width of the closed but naturally propped fracture zone. Indications from this experiment are that once a hydraulic fracture has been created, there is enough natural propping that a conductive zone persists even when the fracture is deflated. With the fracture closed, it seems that a higher proportion of current goes up the borehole to cause greater signal from the cemented-in liner. 


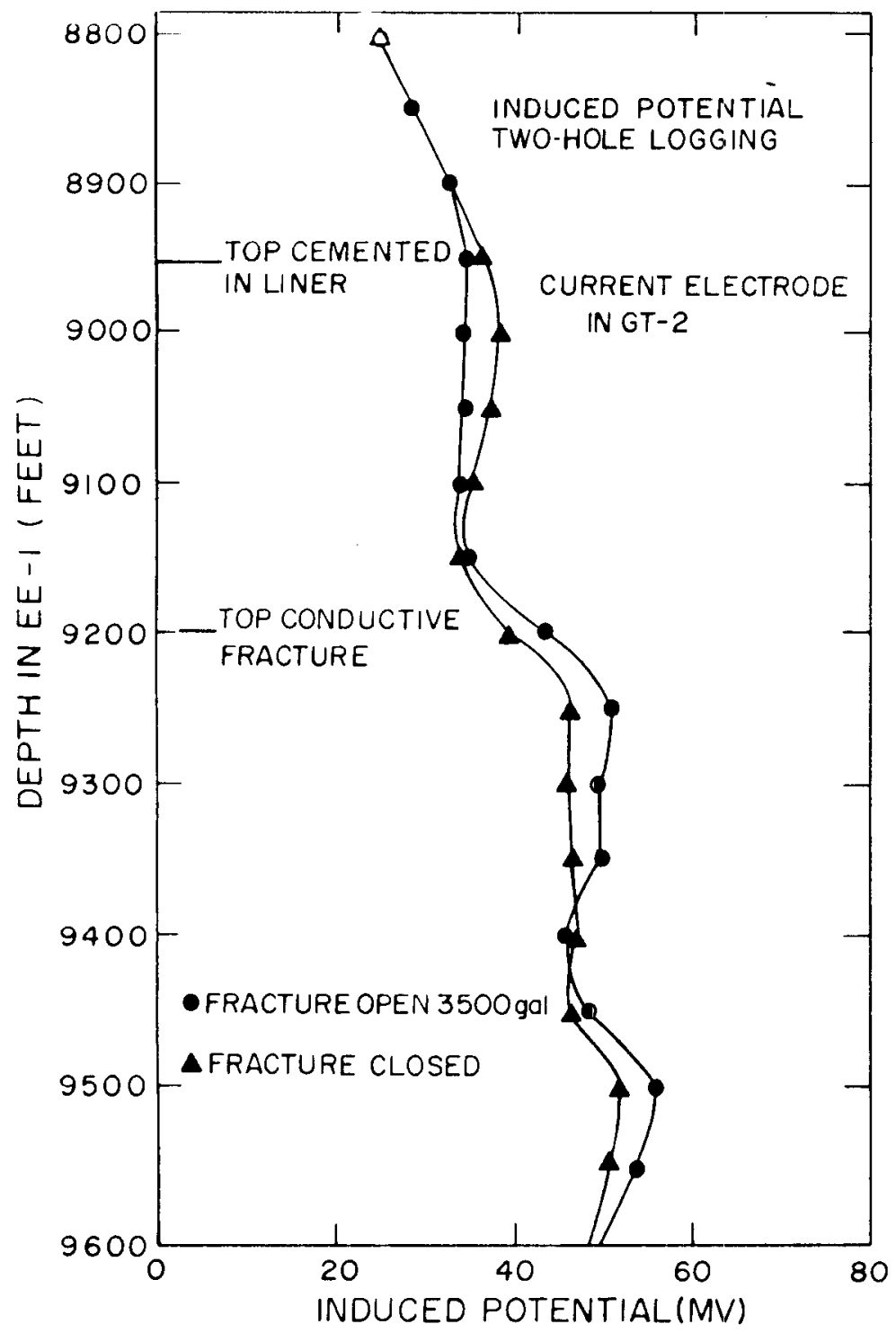

Fig. 3.

Induced potential detection of fracture in GT-2.

Fig. 4 .

Induced potential detection of fracture in EE-1.

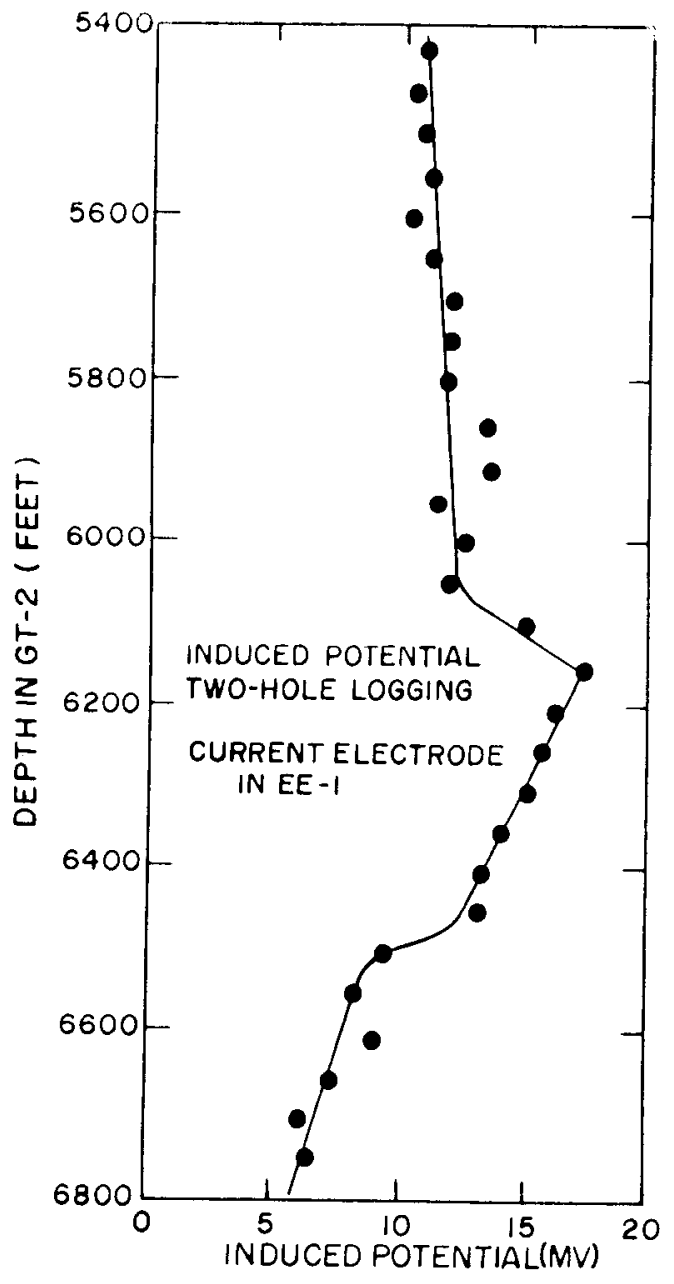


A similar experiment was done to electrically define a hydraulic fracture in EE-1. An 18-m (60-ft) zone of uncased hole was pressurized below $1957 \mathrm{~m}$ (6420 ft) which was the bottom of the cemented-in casing. The current electrode was positioned at the bottom of the uncased portion of the hole that had previously been pressurized to produce a hydraulic fracture. EE-1 then was pressurized to inflate the fracture, and electrical current with a 7-sec period was caused to flow between the bottom-hole electrode and the surface electrode $1.6 \mathrm{~km}$ southwest of EE-1. Results of the potential field measurement are shown in Fig. 4. The conductive zone of the inflated fracture is very well defined, lying between $1875 \mathrm{~m}$ ( $6150 \mathrm{ft})$ and $1981 \mathrm{~m}$ (6500 ft). In this example, again we see an electrical effect from the cemented-in steel liner above the uncased hole. In the region of the liner, signals do not fall off nearly as rapidly as would be expected in an uncased zone and as was found in the uncased region below the fracture

In the two mise à la masse experiments discussed above, there was no opportunity to do a background experiment to establish the effect of the casing or natural rock anisotropies before hydraulic fracturing was done. It is hoped that, in the future, background measurements can be taken before fractures are made. However, results indicate that in both examples the conductive fracture zone was well defined.

III. NATURAL SELF-POTENTIAL (SP) MEASUREMENTS

A spontaneous or electrical self-potential (SP) $\log$ is a record of naturally occurring potential differences between a fixed surface electrode and a moveable electrode in the column of mud or water in the borehole. A relatively stable material such as lead is used for both electrodes and any constant potential difference between the surface electrode and the one downhole is usually balanced out by an adjustable potential difference (or bucking voltage) from a potentiometer circuit. As the surface electrode is stationary, its electrical potential is constant. Thus an SP $10 g$ is a record of variations in potential of the downhole electrode; see the left portion of Fig. 1 where $R$ is the recorder.

The difference in steady potential between the surface electrode and the downhole electrode may be caused by differences of salinity or $\mathrm{pH}$ differences 
at the two electrode locations. This is bucked out at the surface before amplifying and recording so that higher gains can be used to record small variations in potential downhole.

Several sources may contribute to varying potentials in the granite or crystalline-rock portion of the borehole as follows:

- Variations in ion concentration and type (salinity variations).

- Variations in $\mathrm{pH}$.

- Ion mobility variations between hot and cold fluids (thermal electric effects).

- Electrofiltration and streaming potential effects.

If a hydraulic fracture is formed in part of the borehole, water not in thermal or chemical equilibrium with the surrounding rock is forced out into the fracture. These transient conditions in addition to water motion or flow into and out of the fracture could be expected to set up potentials that would be recorded on a self-potential $\log$ and thus provide an indication of where the fracture and borehole intersect.

An interesting experiment was done in an 18-m (60-ft) zone of uncased hole, below $1957 \mathrm{~m}$ (6420 ft), which was the bottom of cemented-in casing in EE-1. Figure 5 is a copy of a self-potential $10 g$ in a portion of $\mathrm{EE}-1$. At the 1958-m (6424-ft) depth, the effect of the transition from conductive steel pipe to uncased granite below can be seen. Below casing bottom, the 1 og shows only minor variations. The $18-\mathrm{m}(60-\mathrm{ft})$ zone below the casing then was pressurized to 13.10 $\mathrm{MPa}$ ( $1900 \mathrm{psi}$ ) and a total of 3028 liters ( $800 \mathrm{gal}$ ) was pumped into the zone to hydraulically fracture the rock.

Later, after depressurization of the fracture, a set of SP logs was run at hydrostatic pressure, with additional pressure, and again with the fracture depressurized to hydrostatic (see Fig. 6). The solid line (A) SP curve taken before the second pressure experiment shows a marked change at $1960 \mathrm{~m}$ (6432 ft) compared to the prefracturing SP $\log$ in Fig. 5. This is probably an indication of the main hydraulic fracture that was produced during the first pressurization. An SP indication at a depth of $1965 \mathrm{~m}$ (6446 ft) may be caused by a minor fracture that was opened or created by initial pressurization. As pressure was increased, the dotted SP trace (B) for a pressure of $11.55 \mathrm{MPa}$ (1675 psi) showed a marked change in response of the 1960-m (6432-ft) zone. This potential would be expected to occur as the fracture is reinflated. The maximum pressure reached 


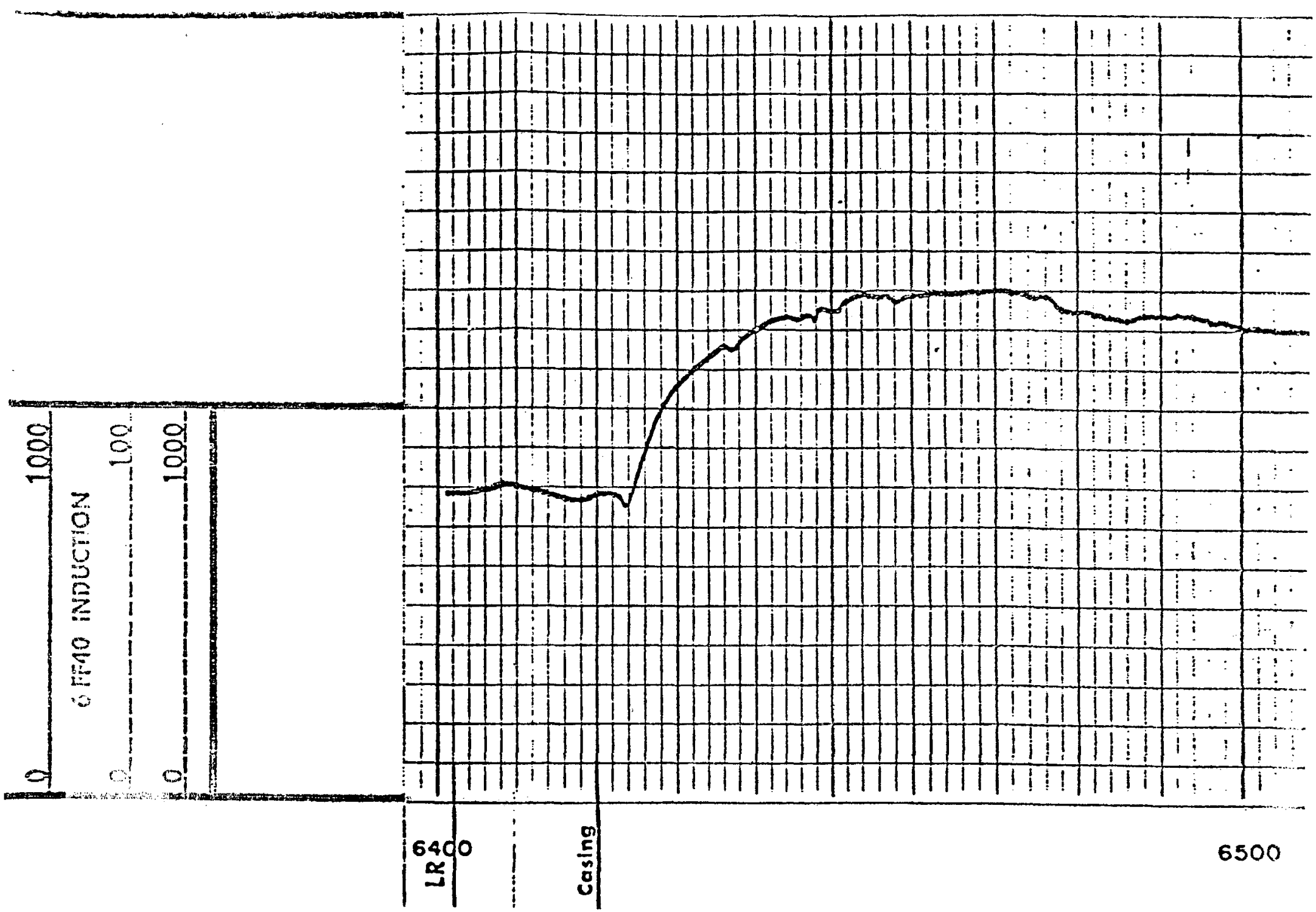

Fig. 5.

Self-potential $\log$ before hydraulic fracturing in EE-1 


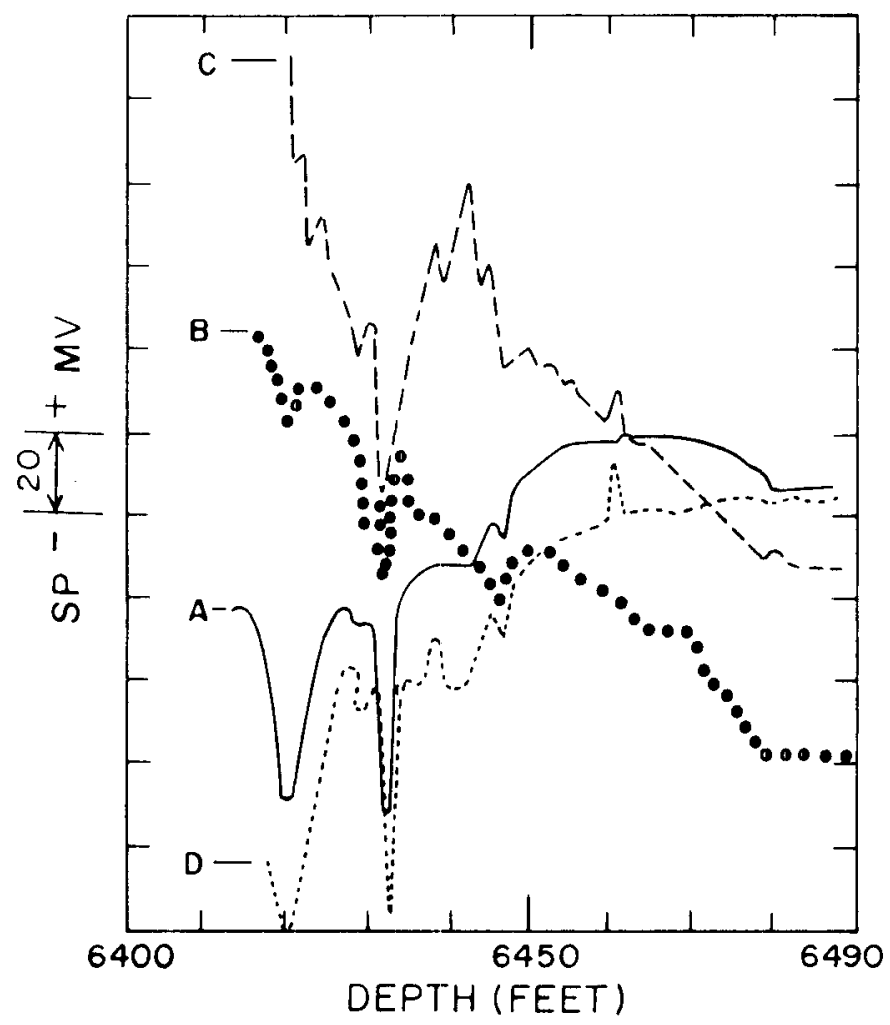

Fig. 6 .

Self-potential logs in EE-1 with and without pressure.
A. Hydrostatic pressure
B. Pressure building $11.55 \mathrm{MPa}$
C. Venting $12.07 \mathrm{MPa}$
D. Hydrostatic pressure

was $14.07 \mathrm{MPa}$ (2040 psi) and after a brief shut-in period the system was depressurized (vented). An SP $\log (C)$ taken at $12.07 \mathrm{MPa}$ (1750 psi) during venting (heavily dashed trace) again shows considerable change in the 1960-m (6432-ft) zone as fluid is leaving the fracture.

The dashed venting trace (C) also shows a new SP indication at the depth of about $1969 \mathrm{~m}$ (6460 ft). This can be seen to coincide with an indication on the lightly dashed trace (D) which is a $\log$ taken $40 \mathrm{~min}$ later after venting. This new signal at $1969 \mathrm{~m}$ (6460 ft) could be caused by a sma1l fracture that was opened during pressurization during this test. It may be noticed that the pre- and post-pressure logs A and D in Fig. 6 are very similar.

During times of change in fracture regions in the holes, natural SP logging helps to determine the postion of fracture. After a fracture has come to 
equilibrium with fluid parameters such as temperature, pressure, salinity, etc., an SP effect may not be evident from the fracture.

When EE-1 had been drilled to a depth of about $2103 \mathrm{~m}$ (6900 ft) or about $146 \mathrm{~m}$ (480 ft) below the cemented-in liner, sonic and electric logs were run within $24 \mathrm{~h}$ of cessation of drilling. The sonic $\log$ shows a possible natural incompetent or fracture zone at a depth of $2080 \mathrm{~m}$ (6825 ft), and an SP signal also was recorded at this depth, as seen in Fig. 7. Very soon after the logging was completed a hydraulic fracturing experiment was tried in this 146-m (480- $\mathrm{ft}$ ) zone of open crystalline rocks below the steel liner. However, the hole would not hold pressure due to leakage into this natural fracture zone. The bottom zone was then packed off and pressures adequate for hydraulic fracturing were achieved in the upper portion of the uncased hole. These experiments were described above.

It should be repeated that the self-potential logging is an excellent and simple method for location of the bottom of steel casing that has been set in the hole. SP logs in Figs. 5 and 6 both give good indications of transition from steel casing to open hole. An additional experiment was done in January 1976 with LASL's SP logging equipment. Results of an SP logging run are shown in Fig. 8. In this run a signal generated by going from cased hole to uncased hole and vice versa can be seen. Several reruns were made, and very good repeatability (see Table I) was achieved as the SP probe passed in and out of the bottom of the casing. Due to different tension on the logging cable going into and out of the hole, a slight difference in depth for a given event is obtained for reverse direction of logging.

Thus, for location of other downhole instrument packages, a single SP electrode could be incorporated in the packages to provide a fixed marker at depth by means of SP response at casing bottom. 
FULL WAVE SONIC LOG
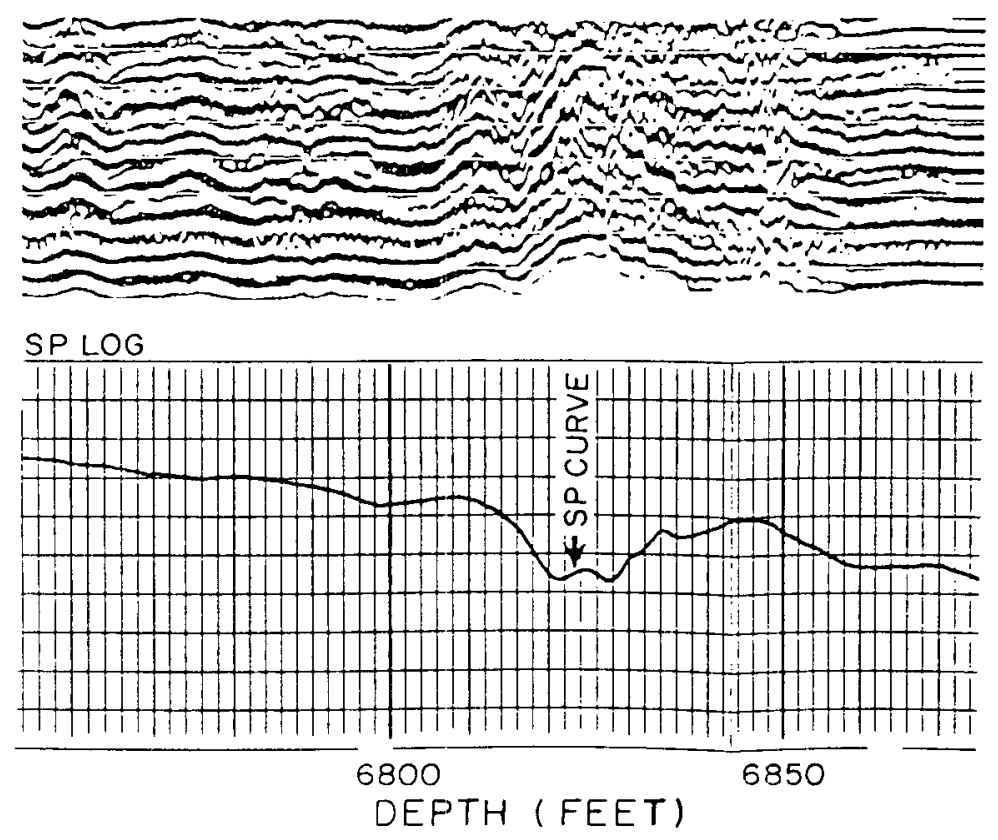

Fis. 7.

Sonic and self-potential detection of natural fracture zone in EE-1.

TABLE I

DEPTH OF CASING BREAK ON SP LOG

Logging In

\begin{tabular}{cc}
\hline $\begin{array}{c}\text { Depth } \\
(\mathrm{m})\end{array}$ & $\begin{array}{c}\text { Depth } \\
\text { (ft) }\end{array}$ \\
\hline 2947.7 & 9671 \\
2947.4 & 9670 \\
2947.4 & 9670 \\
2947.4 & 9670
\end{tabular}

Logging Out

\begin{tabular}{cc}
\multicolumn{2}{c}{ Logging Out } \\
\hline $\begin{array}{c}\text { Depth } \\
\text { (m) }\end{array}$ & $\begin{array}{c}\text { Depth } \\
\text { (ft) }\end{array}$ \\
\hline 2945.9 & 9665 \\
2945.9 & 9665 \\
2945.9 & 9665 \\
2945.9 & 9665
\end{tabular}









\section{REFERENCES}

1. D. W. Brown, "The Potential for Hot-Dry-Rock Geothermal Energy in the Western United States," Hearings before the Subcommittee on Energy of the Committee on Science and Astronautics, U. S. House of Representatives, Ninety-Third Congress, First Session on H. R. 8628, H. R. 9658, September 11,13 , and 18, 1973, pp. 129-138.

2. M. C. Smith, "Geothermal Power," Physics and the Energy Problem--1974, edited by M. D. Fiske and W. W. Havens, Jr. (American Institute of Physics, New York, 1974), pp. 401-411.

3. C. Schlumberger, Etudes sur 1a Prospection Electrique du sous sol (Gauthiers-rillars, Paris, 1920).

4. H. Braekken, "Deep Ore Exploration by Electrical Methods," Geophys. Prospecting 1 , v. IX (1961).

5. H. Braekken, "Deep Ore Prospecting by Charged Potential Studies I," Det Kongelige Norske Videnskabers Selskabs Forhandlinger 22, Bind. 32 (1959).

6. F. G. West, P. R. Kintzinger, and A. W. Laugh1in, "Geophysical Logging in Los Alamos Scientific Laboratory Geothermal Test Hole No. 2," Los Alamos Scientific Laboratory report LA-6112-MS (November 1975).

7. G. R. Jiracek and P. R. Kintzinger, "Deep Electrical-Resistivity Investigations Coupled with "Dry" Geothermal Experiments in New Mexico," Geophysics 40, p. 175 (1975).

8. Paul R. Kintzinger, "Geophysical Measurements at Fenton Hi11," E丹S $\underline{57}$, No. 4, (1976). 